\title{
1 Effect of thermal maturation on plant-derived terpenoids and leaf wax $n$-alkyl
}

2 components

4 Aaron F. Diefendorf ${ }^{a^{*}}$, Douglas T. Sberna ${ }^{\mathrm{a}, \mathrm{b}}$, David Winship Taylor ${ }^{\mathrm{c}}$

$5 \quad{ }^{a}$ Department of Geology, University of Cincinnati, Cincinnati, OH 45221, USA

$6 \quad{ }^{\mathrm{b}}$ School of Earth and Environmental Sciences, James Cook University, Cairns, QLD 4870, Australia

$7 \quad{ }^{\mathrm{c}}$ Department of Biology, Indiana University Southeast, New Albany, IN 47150, USA

$9 \quad{ }^{*}$ Corresponding Author. Tel.: +1-513-556-3787.

10 E-mail address: aaron.diefendorf@uc.edu (A.F. Diefendorf).

11

12 Keywords: plant biomarkers, $n$-alkyl lipids, plant-derived terpenoids, hydrous pyrolysis, alteration,

13 diagenesis, compound specific carbon isotope analyses 


\section{ABSTRACT}

16 Plant biomarkers, such as terpenoids and leaf wax components ( $n$-alkanes, $n$-alkanoic acids and $n$ -

17 alkanols), are frequently found in sediments and can be used, often in association with stable carbon (and

18 hydrogen) isotope measurements, as paleovegetation and paleoclimate proxies. However, few controlled

19 studies have monitored plant biomarker alteration to determine if certain plant biomarkers are

20 preferentially lost relative to more recalcitrant forms. To investigate the role of selective alteration and

21 degradation of plant biomarkers, hydrous pyrolysis was used to artificially mature leaves from four plant

22 species, including the deciduous angiosperms Acer rubrum and Platanus occidentalis, the deciduous

23 conifer Taxodium distichum and the evergreen conifer Pinus sylvestris. Leaves were artificially matured

24 at temperatures ranging from 150 to $330^{\circ} \mathrm{C}$ for $72 \mathrm{~h}$ to simulate maturation. With increasing temperature,

25 functionalized di- and triterpenoidyields decreased, with a greater loss of triterpenoids at lower

26 temperature. Both diterpene and triterpene yield increased during maturation up to 310 to $320^{\circ} \mathrm{C}$. A

27 greater amount of diterpenes and triterpenes was generated for P. sylvestris and A. rubrum, respectively,

28 and might be related to differences in terpenoid starting composition. Terpenols were preferentially

29 converted to terpenes over terpenoic acids. Taken together, hydrous pyrolysis of plant biomarkers

30 indicates that paleovegetation reconstruction from terpenoids can be informative, but only as a qualitative

31 vegetation proxy. The $n$-alkane yield largely increased up to $320^{\circ} \mathrm{C}$, whereas the $n$-alkanol yiels mainly

32 decreased with increased maturity. The $n$-alkanoic acids initially increased, but then decreased. The stable

33 carbon isotopic composition $\left(\delta^{13} \mathrm{C}\right)$ of the $n$-alkanes was generally, though not universally, constant up to

$34200^{\circ} \mathrm{C}$. Above this, the $\delta^{13} \mathrm{C}$ values of individual chain length hydrocarbons, for some species, changed

35 by ca. $2 \%$. This suggests that $n$-alkane $\delta^{13} \mathrm{C}$ values should be unaltered in immature rocks, but can vary in

36 the catagenic stage of maturation (oil window). 


\section{Introduction}

Plant biomarkers, such as diterpenoids, higher plant triterpenoids and leaf wax $n$-alkyl components, are useful for paleovegetation and paleoclimate research. For example, plant-derived terpenoids have been used extensively to understand the timing of the rise of angiosperms, as paleovegetation proxies and as chemotaxonomic indicators (Moldowan et al., 1994; Otto et al., 1997, 2005; Otto and Simoneit, 2001; Bechtel et al., 2002, 2008; Hautevelle et al., 2006b; Taylor et al., 2006; Diefendorf et al., 2011; Schnell et al., 2014). Other studies have focused on plant leaf wax components, such as $n$-alkanes and $n$-alkanoic acids, and their carbon isotope signatures have been used to understand past change in the carbon cycle (e.g. Smith et al., 2007; Handley et al., 2008; Whiteside et al., 2010; Diefendorf et al., 2011). Many studies have focused on the alteration of terpenoids and $n$-alkyl compounds within sediments and oils (ten Haven and Rullkötter, 1988; ten Haven et al., 1992; Killops and Frewin, 1994; Rullkötter et al., 1994; Otto and Simoneit, 2001; Nakamura et al., 2010); however few studies have examined how these compounds are altered from their original biological structures (Gupta et al., 2007a; Lu et al., 2013).

The utility of terpenoids as quantitative or even qualitative indicators of paleovegetation is complicated because of differential preservation. Diefendorf et al. (2014) found that angiosperm-derived triterpenoids in Paleogene rocks were lower in concentration than expected based on the paleovegetation, reconstructed from fossil leaves and by taking into account lipid production rate measured in living plants. However, gymnosperm-derived tricyclic diterpenoids were consistent with paleovegetation estimates. Based on that work and that of others (Bechtel et al., 2003; Jacob et al., 2007; Nakamura et al., 2010), various factors can influence terpenoid concentration, thereby making paleovegetation reconstruction based on terpenoids challenging. Many questions remain as to why triterpenoids are under represented relative to diterpenoids or $n$-alkanes in geologic archives.

61 
To investigate the role of selective alteration and degradation of plant biomarkers, we utilized hydrous pyrolysis to artificially mature plant specimens. The method has been used with material from living

64 plants to allow better comparison with biomarkers found in geological samples (Taylor et al., 2006). The 65 approach tries to mimic natural maturation by heating samples in a sealed reactor with liquid water for a period of $72 \mathrm{~h}$ (Lewan et al., 1979; Lewan, 1993; Jaeschke et al., 2008). The technique is different from

67 confined pyrolysis, which uses a confining pressure and heat, but without added water, to simulate 68 maturation (e.g. Gupta et al., 2007b). Comparison between hydrous pyrolysis and confined pyrolysis of

69 immature source rocks indicates that hydrous pyrolysis results in a greater yield of expelled hydrocarbons that have molecular composition more petroleum-like, with overall lower yield of aromatized organic matter due to the presence of water (Lewan, 1993; Michels and Landais, 1994; Michels et al., 1995a, b). Hydrous pyrolysis ignores the importance of biological degradation during burial, oxidation/reduction variation in sediments and early sediment diagenesis (Wakeham et al., 1980; Hedges and Prahl, 1993; Jacob et al., 2007). Nonetheless, it does provide insight into the role that maturation plays in the alteration and preservation of biomarkers (e.g. Jaeschke et al., 2008).

\section{Material and methods}

\subsection{Samples}

80

81 Plant samples were collected in June 2013 from a small forest near the University of Cincinnati (USA; $\left.39.1378^{\circ} \mathrm{N}, 84.5182^{\circ} \mathrm{W}\right)$. Species collected included the deciduous angiosperms Acer rubrum (red maple) and Platanus occidentalis (American sycamore), the deciduous gymnosperm Taxodium distichum (bald cypress) and the evergreen gymnosperm Pinus sylvestris (Scots pine). From each plant, ca. $100 \mathrm{~g}$ leaf tissue was collected $2 \mathrm{~m}$ above the ground from the sun-exposed side of the trees. Samples were rinsed with deionized water, frozen and freeze-dried. 
Hydrous pyrolysis was carried out following Lewan (1993) and Jaeschke et al. (2008). The reactors were

9175 were $\mathrm{ml}$ type 316 stainless steel (Parr Instrument Company, Moline, IL, USA; Model No 4740). They

92 were filled with $400 \mathrm{mg}$ leaves and $27 \mathrm{~g}$ deionized water. A type 316 stainless steel wire cloth $(0.86 \mathrm{~mm}$

93 open mesh) was inserted to keep the tissue submerged. Reactors were sealed with PTFE washers, purged

94 with $\mathrm{N}_{2}$ after the bolts had been tightened to $33.0 \mathrm{Nm}$ and then isothermally heated in a muffle furnace for

$9572 \mathrm{~h}$ at temperatures from 150 to $330^{\circ} \mathrm{C}$. Oven temperature was monitored with a type $\mathrm{K}$ thermocouple

96 (Omega, Stamford, CT, USA) and temperature was $\pm 1^{\circ} \mathrm{C}$ for the duration of the heating. After cooling

97 the reactors, gases were vented and the contents filtered (Whatman GF/F) to isolate the pyrolysate, which

98 was freeze-dried prior to extraction. Hydrous pyrolysis sample replicates were not carried out as part of

99 this study.

100

101

\subsection{Extraction and fractionation}

102

103 Pyrolysates and fresh leaf material (200 mg) were extracted using accelerated solvent extraction (ASE;

104 Dionex 350) with 2:1 (v/v) dichloromethane (DCM)/MeOH with three extraction cycles at $10.34 \mathrm{MPa}$

105 and $100^{\circ} \mathrm{C}$. The filtered water and expelled oil fraction from hydrous pyrolysis was liquid/liquid

106 extracted with hexane and combined with the ASE fraction. One half of the total lipid extract (TLE) was

107 fractionated into maltenes and asphaltenes by asphaltene precipitation with hexane/DCM (40:1, v/v)

108 followed by centrifugation. The maltene fraction was separated into polar and apolar fractions over $\mathrm{Al}_{2} \mathrm{O}_{3}$

109 powder $\left(50-200\right.$ mesh, activated at $\left.150^{\circ} \mathrm{C}\right)$ with hexane/DCM $(9: 1, \mathrm{v} / \mathrm{v})$ and $\mathrm{DCM} / \mathrm{MeOH}(1: 1, \mathrm{v} / \mathrm{v})$,

110 respectively. The remaining TLE fraction was saponified to cleave ester groups with $0.5 \mathrm{~N} \mathrm{KOH}$ in

$111 \mathrm{MeOH} /$ water $(3: 1, \mathrm{v} / \mathrm{v})$ for $2 \mathrm{~h}$ at $75^{\circ} \mathrm{C}$. The hydrocarbons in the apolar maltene fraction were analyzed

112 using gas chromatography (GC) and GC-mass spectrometry (MS). They were further fractionated into a

113 saturated and unsaturated fraction for GC-isotope ratio MS (IRMS) analysis with $0.5 \mathrm{~g}$ of $5 \% \mathrm{Ag}^{+}$ 
114 impregnated silica gel (w/w) and eluting with $4 \mathrm{ml}$ hexane and $4 \mathrm{ml}$ EtOAc, respectively. Functionalized

115 compounds in the saponified TLE fraction were analyzed with GC and GC-MS as TMS derivatives and

116 were derivatized with $\mathrm{N}, \mathrm{O}$-bis(trimethylsilyl)trifluoroacetamide (BSTFA; Sigma Aldrich) at $70{ }^{\circ} \mathrm{C}$ for 15

117 min. For GC-IRMS analysis of the $n$-alkanoic acids and $n$-alkanols in the TLE fraction, samples were

118 further fractionated with aminopropyl-bonded silica gel following Sessions (2006), as reported by

119 Diefendorf et al. (2012). The $\delta^{13} \mathrm{C}$ values of derivatized samples were corrected for TMS C addition using 120 isotope mass balance (Section 2.5).

121

122 2.4. Lipid assignment and quantification

124 Assignment and quantification was made with an Agilent 7890A GC instrument fitted with a multi mode

125 inlet operated in pulsed splitless mode at $320^{\circ} \mathrm{C}$ and interfaced with an Agilent 5975C quadrupole mass 126 selective detector (MSD, at $70 \mathrm{eV}$ ) and a flame ionization detector (FID). Compounds were separated on 127 a fused silica column (Agilent J\&W DB-5ms; $30 \mathrm{~m} \times 0.25 \mathrm{~mm}, 25 \mu \mathrm{m}$ ) with a $5 \mathrm{~m}$ guard column 128 (RestekRxi, $5 \mathrm{mx} 0.32 \mathrm{~mm}$ ). The oven program was: $60{ }^{\circ} \mathrm{C}(1 \mathrm{~min})$ to $320^{\circ} \mathrm{C}$ (held $\left.15 \mathrm{~min}\right)$ at $6{ }^{\circ} \mathrm{C} / \mathrm{min}$. 129 The column effluent was split (1:1) between the FID and MSD with a 2-way splitter (Agilent G3180B) at 130 a constant $182 \mathrm{~Pa}$. Compounds were assigned using authentic standards, library databases (NIST 2008 131 and Wiley 2009), published spectra, spectral interpretation and retention times. Additional unknown 132 compounds are listed in Table A.3 with associated molecular mass and characteristic ions.

134 For FID quantification, maltenes were dissolved quantitatively in hexane spiked with 1-1'-binaphthyl. For 135 analysis of the polar compounds in the saponified TLE fractions, aliquots were dissolved in pyridine 136 spiked with 2-dodecanol, phthalic acid and undecanoic acid. Peak areas were normalized to internal 137 standards and converted to concentration values using external standard response curves. For 138 hydrocarbons, the external standard was a mixture of $\mathrm{C}_{7}$ to $\mathrm{C}_{40} n$-alkanes (Sigma Aldrich) and for polar 
compounds a mixture of triterpenoids, $n$-alkanols and $n$-alkanoic acids. Compound concentration and

140 yields $(\mu \mathrm{g} / \mathrm{g})$ were normalized to the mass of dry leaf starting material.

142 The average chain length (ACL) of $n$-alkanes was calculated (Eq. 1) where $n$-alkane concentrations are 143 converted to chain length numbers(Eglinton and Hamilton, 1967).

144

145

146

$$
\mathrm{ACL}=25[\mathrm{C} 25]+27[\mathrm{C} 27]+\ldots 35[\mathrm{C} 35][\mathrm{C} 25]+[\mathrm{C} 27] \ldots[\mathrm{C} 35](
$$

To compare differences in odd chain length preference, the carbon preference index (CPI) was calculated (Eq. 2; Marzi et al., 1993).

$$
\mathrm{CPI}=[\mathrm{C} 23]+[\mathrm{C} 25] \ldots[\mathrm{C} 31]+\mathrm{C} 25+[\mathrm{C} 27] \ldots[\mathrm{C} 33] 2 \mathrm{C} 24+[\mathrm{C} 26] \ldots[\mathrm{C} 32]
$$

\subsection{Carbon isotope analysis}

GC-IRMS was performed with a Thermo Trace GC Ultra coupled to a Thermo Electron Delta V Advantage IRMS instrument via an Isolink combustion furnace. GC conditions were similar to the above with the exception of a faster ramp rate $\left(8^{\circ} \mathrm{C} / \mathrm{min}\right)$. Isotopic abundances were determined relative to a reference gas calibrated with the average of compounds in Mix A (A. Schimmelmann, Indiana University). Carbon isotope values of samples (S) are reported in delta notation relative to the standard Vienna Peedee Belemnite (VPDB) as $\left.\delta^{13} \mathrm{C}=\left[{ }^{13} \mathrm{R}_{\mathrm{S}} /{ }^{13} \mathrm{R}_{\mathrm{VPDB}}\right)-1\right]$ where ${ }^{13} \mathrm{R}={ }^{13} \mathrm{C} /{ }^{12} \mathrm{C}$. Carbon isotope values of $n$-alkanols and $n$-alkanoic acids were determined on the trimethylsilyl (TMS) derivatives. The $\delta^{13} \mathrm{C}$ values were corrected for the TMS carbon addition with an isotope mass balance after determining 
164 the $\delta^{13} \mathrm{C}$ of the TMS carbon $(-46.08 \pm 0.45,1 \sigma, \mathrm{n}=5)$ with phthalic acid (A. Schimmelmann). Isotope

165 precision and accuracy were monitored with a co-injected $n$ - $\mathrm{C}_{38}$ alkane standard and was $0.16 \%$ ( $1 \sigma$;

$166 \mathrm{n}=76)$ and $-0.01 \%(\mathrm{n}=76)$, respectively, over the course of analysis.

167

\section{Results and discussion}

\subsection{Thermal alteration of plant-derived terpenoids}

172 The four plant species were artificially matured using hydrous pyrolysis for $72 \mathrm{~h}$ at temperatures ranging 173 from 150 to $330{ }^{\circ} \mathrm{C}$. The amounts of pyrolysate for each species generally decreased, as a proportion (\%) 174 of starting mass, with increasing temperature (Fig.1). The diterpenoic acid and alcohol yield increased 175 initially for $P$. sylvestris and then decreased, whereas for T. distichum, yield decreased throughout the experiment (Fig. 2, Table 1). For P. sylvestris, the diterpenoic acid and alcohol yield was much higher at

$177150{ }^{\circ} \mathrm{C}$ and $200{ }^{\circ} \mathrm{C}$ than for the starting composition. The increase was primarily due to an increase in 178 dehydroabietic acid and abietic acid. Since the unaltered leaf tissue was not hydrolyzed following lipid 179 extraction, structurally bound terpenoids were not considered nor did we compare resin concentrations.

180 The increase in terpenoid compounds for $P$. Sylvestris is consistent with a bound diterpenoid source that 181 was cleaved and released during heating, resulting in a higher yield of diterpenoids following hydrous 182 pyrolysis. Alternatively, it could be related to a greater concentration of resin within the needles that is 183 converted to extractable compounds following heating. Egenberg et al. (2002) found that the heating $P$. 184 sylvestris tar resulted in an increased yield of dehydroabietic acid and abietic acid, similar to our results.

186 Diterpenes were detectable in the first maturation step of $150{ }^{\circ} \mathrm{C}$. They were likely produced through 187 dehydrogenation and decarboxylation that transformed diterpenoic acids and alcohols to olefinic and 188 aromatic diterpenes. Diterpene yield increased most at 300 to $310{ }^{\circ} \mathrm{C}$ and might reflect a greater 
conversion of functionalized compounds to hydrocarbons (Tissot and Welte, 1984; Farrimond et al.,

190 1998; Vandenbroucke and Largeau, 2007).

192 The two conifer species were chosen because they have very different diterpenoid composition

193 (Diefendorf et al., 2012). For example, P. sylvestris contains various acids within the abietane and

194 pimarane classes, with dehydroabietic acid, abietic acid, sandaracopimaric acid and isopimaric acid the

195 most abundant (Supplementary Table A.1). T. distichum also contains sandaracopimaric acid, as well as

196 ferruginol and 2,3-dehydroferruginol. Compared with the starting composition, there were some

197 similarities in the diterpenoid composition following artificial maturation. For example, both species

198 contained abietene and pimarene compounds such as norabietatriene, norabietatetraene isomers,

199 dehydroabietane and pimaradienes. However, $P$. sylvestris had a sizeable yield of retene, 1,2,3,4-

200 tetrahydroretene and a series of unidentified tricyclic $\mathrm{C}_{19}$ diterpenes (Table A.3) that were not detected in

201 the T. distichum samples. The differences may be attributed to a high concentration of abietic acid and

202 dehydroabietic acid in the starting composition of $P$. sylvestris, whereas these compounds were not

203 detected in T. distichum. This is consistent with abietic acid and dehydroabietic acid as precursors for

204 retene and other aromatic abietene structures (Simoneit, 1986; Hautevelle et al., 2006a). However, it

205 implies that ferruginol and 2-3-dehydroferruginol are not altered to retene, at least under the experimental

206 conditions used here. This conflicts with geologic studies of sediments with Taxodium and the related

207 Metasequoia, where retene is commonly observed (e.g. Otto et al., 1997; Diefendorf et al., 2014) and

208 suggests that hydrous pyrolysis may not be directly comparable with sediment-based studies, as has been

209 suggested for confined pyrolysis (Hautevelle et al., 2006a).

210

211 The triterpenoids in the starting composition of the angiosperm species were unique between species,

212 although the total concentration was not that different (Fig. 2). A. rubrum was composed primarily of the

213 triterpenols $\alpha$ - and $\beta$-amyrin, friedelin (a ketone) and an unknown pentacyclic triterpenoid (Table A.3). In 
contrast, $P$. occidentalis contained oleanolic acid and betulinic acid, and two additional unknown

215 pentacyclic triterpenoids.

217 With heating, the composition changed significantly (Fig. 2, Table 1). Friedelin was present up to $310^{\circ} \mathrm{C}$.

218 For P. occidentalis, oleanolic acid was present only in the unaltered samples and betulinic acid and an

219 unknown pentacyclic triterpenoid were present only in the $150{ }^{\circ} \mathrm{C}$ sample. The hydrocarbons only

220 contained olefinic triterpenes and no aromatic triterpenes were detected. For A. rubrum, the triterpenes

221 were detectable at $150{ }^{\circ} \mathrm{C}$ and increased nearly 10 fold at $250{ }^{\circ} \mathrm{C}$ and were then rapidly lost by $320{ }^{\circ} \mathrm{C}$.

222 The compounds produced included olean-12-ene, olean-18-ene, olean-13(18)-ene and D:A-friedoolean-6-

223 ene. P. occidentalis had a very low yield of triterpenes, with olean-18-ene the most abundant, but only

224 with ca. $7 \mu \mathrm{g} / \mathrm{g}$. These differences appear to have had an important influence on the triterpene

225 composition of the matured samples. If this pattern is similar for natural samples, then species that have a

226 greater concentration of triterpenols are more likely to be represented in the geologic record than species

227 with primarily triterpenoic acid compounds.

229 With increasing maturation, the di- and triterpenoids had very different patterns. For the functionalized

230 compounds, diterpenoic acids and alcohols were common in both conifer species up to $330{ }^{\circ} \mathrm{C}$. However,

231 triterpenoids were present only up to $200{ }^{\circ} \mathrm{C}$ for $P$. occidentalis. The pentacyclic triterpenoid, friedelin-3-

232 one, was detectable up to $310^{\circ} \mathrm{Cfor}$ A. rubrum. For the hydrocarbons, the diterpenes increased in olefinic

233 and aromatic compounds up to 320 to $330^{\circ} \mathrm{C}$ and were near the highest yield at $330{ }^{\circ} \mathrm{C}$. In contrast, the

234 triterpenes, which were all olefinic, increased between 250 and $310^{\circ} \mathrm{C}$, but were almost entirely lost by

$235320^{\circ} \mathrm{Cfor}$ A. rubrum. Based on these four species, it appears that triterpenoids, both functionalized and

236 non-functionalized, are lost from the bitumen fraction at lower maturity than the diterpenoids. It is

237 possible that our experimental approach does not fully mimic natural maturation. Specifically, our study

238 did not include the addition of substrates (Peters et al., 1990), such as clay, which can be important in

239 catalyzing organic matter transformation (Frenkel and Heller-Kallai, 1977). The inclusion of clays has 
been shown to aromatize triterpenes (Hayatsu et al., 1987) and, as indicated above, aromatic triterpenes

241 were not detected in this study, despite being common in geologic sediments (Wakeham et al., 1980;

242 Chaffee and Johns, 1983; Stout, 1992; Bechtel et al., 2003; Jacob et al., 2007; Nakamura et al., 2010).

243 Regardless, our results indicate that diagenetic bias is not simply a gymnosperm vs. angiosperm problem,

244 but rather that there is a more complicated bias that is dependent on the suite of terpenoids present in the 245 original biomass.

247 For paleovegetation studies, the results might prove useful for determining when floral reconstructions 248 are least biased. At low maturity, the similar pattern of hydrocarbon formation and functionalized 249 compound loss would result in minor vegetation bias in paleovegetation reconstruction when plants 250 contain a terpenoid composition similar to P. sylvestris, ., distichum and A. rubrum. However, if the 251 plants have a triterpenoid composition similar to P. occidentalis, which is rich in oleanolic acid and 252 betulinic acid, then paleovegetation studies based on the biomarker content may significantly underestimate angiosperms. At higher maturity, triterpenes would be significantly lost and angiosperm 254 vegetation would therefore be underestimated. composition changes with heating and to determine if $n$-alkanoic acids and $n$-alkanols are degraded to $n$ -

260 alkanes upon heating. We focused on the $n$-alkanes, $n$-alkanoic acids and $n$-alkanols, as these are the most 261 commonly studied (Pancost and Boot, 2004; Freeman and Pancost, 2014). In the unaltered plant samples

262 (Fig. 3, Table 1), $n$-alkanes were much more abundant in the angiosperms (ca. $250 \mu \mathrm{g} / \mathrm{g}$ ) than in the 263 conifers $(<0.1 \mu \mathrm{g} / \mathrm{g})$. The $n$-alkanoic acids were also of higher abundance in the angiosperms (ca. 210 $264 \mu \mathrm{g} / \mathrm{g}$ vs. ca. $50 \mu \mathrm{g} / \mathrm{g}$ in the conifers). In contrast, the $n$-alkanols were nearly the same in concentration in 265 both $P$. occidentalis and T. distichum (ca. $1450 \mu \mathrm{g} / \mathrm{g}$ ), whereas A. rubrum and P. sylvestris had a much 
lower concentration (675 and $69 \mu \mathrm{g} / \mathrm{g}$, respectively). These values are broadly similar to those reported in other studies of living plants, including the high $n-\mathrm{C}_{28}$ alkanol concentration in $T$. distichum

268

(Rommerskirchen et al., 2006; Vogts et al., 2009; Diefendorf et al., 2011; Bush and McInerney, 2013;

Tipple and Pagani, 2013).

Artificial maturation of the plant samples resulted in changes in $n$-alkyl lipid composition and yield, although the changes were not always consistent among species for the different wax types (Figs. 3 and 4). For example, $n$-alkanoic acid yield initially increased for $A$. rubrum and $T$. distichum. Above $250{ }^{\circ} \mathrm{C}$, the behavior of $n$-alkanoic acid yield was rather variable and does not seem to follow a pattern. For example, $T$. distichum reached a maximum at $200{ }^{\circ} \mathrm{C}$, followed by low to not detectable $n$-alkanoic acids until $330^{\circ} \mathrm{C}$ when yield increased. The composition of $n$-alkanoic acids was also different between lower and higher temperatures. For example, the $n$-alkanoic acids in $T$. distichum were dominated by the $n$ - $\mathrm{C}_{30}$ at $150{ }^{\circ} \mathrm{C}$, whereas at $330^{\circ} \mathrm{C}$, they are dominated by $n$-C $\mathrm{C}_{2}$ (Table A.1). In contrast to the $n$-alkanoic acids, the $n$-alkanols progressively decreased in yield with increased temperature (Fig. 3). In general, $n$-alkane yield initially exceeded that in the unaltered samples, although the temperature at which this occurred differed for each species. For example, $T$. distichum had the highest $n$-alkane yield at $200^{\circ} \mathrm{C}$ and $330^{\circ} \mathrm{C}$, whereas $A$. rubrum had the highest at $310^{\circ} \mathrm{C}$. Regardless, both species had a drop in $n$-alkane yield at 250 ${ }^{\circ} \mathrm{C}$. ACL and CPI (Fig. 3) generally decreased with increasing temperature, with the exception of $P$. sylvestris, for which there was an increase in CPI at $330^{\circ} \mathrm{C}$.

The observed decrease in $n$-alkanols and $n$-alkanoic acids, above $200{ }^{\circ} \mathrm{C}$, is consistent with studies that found that $n$-alkyl lipids are polymerized to insoluble macromolecules during fossilization of leaves (Stankiewicz et al., 2000; Gupta et al., 2007a, b; Gupta, 2014). As temperature increased in this study, $n$ alkanes were generated. For example, $T$. distichum and $P$. sylvestris $n$-alkane yields were below detection limit in the untreated samples. As the two species were heated, $n$-alkanes from $\mathrm{C}_{15}$ to $\mathrm{C}_{36}$ were produced. This is consistent with other studies that have suggested polymerized macromolecules as a source of long 
292 chain $n$-alkanes in fossil leaves and the source of these $n$-alkanes may include $n$-alkanoic acids, $n$ -

293 alkanols, cutan, cutin and other plant lipids (Eglinton, 1994; Finch and Freeman, 2001; Gupta et al., 2006

294 , 2007a, b; Gupta, 2014). The exact lipid source of the $n$-alkanes generated in this study cannot be

295 determined, but there are likely to be multiple sources. The latter likely vary among species as individual

296 species have different lipid composition (Eglinton and Hamilton, 1967; Gupta et al., 2006; e.g. Bush and

297 McInerney, 2013) and this may explain some of the variability observed here among species.

\subsection{Leaf wax carbon isotopes and maturity}

301 In all species ,the $\delta^{13} \mathrm{C}$ values of the $n$-alkanes were similar between unaltered samples and samples 302 heated up to ca. $200{ }^{\circ} \mathrm{C}$ (Fig. 5; Table A.2), with the exception of $\mathrm{C}_{31}$ in T. distichum. Above $200{ }^{\circ} \mathrm{C}$, $303 \delta^{13}$ Cvalues changed for some species and chain length. For example, the values decreased for $A$. rubrum 304 and P. sylvestris, whereas $P$. occidentalis stayed nearly constant, and $T$. distichum varied by chain length $305\left(\mathrm{C}_{29}\right.$ increased, all others decreased). For all species, $\mathrm{C}_{29}$ had the smallest variation in $\delta^{13} \mathrm{C}$ and the total 306 change was $<1 \%$. For comparison, $\delta^{13} \mathrm{C}$ values of the unaltered $n$-alkanoic acids and $n$-alkanols are 307 shown in Fig. 5. As mentioned above, these two groups of lipids can serve as precursors for $n$-alkanes 308 during maturation. The $\delta^{13} \mathrm{C}$ values of the $n$-alkanoic acids and $n$-alkanols did not seem to influence the $309 \delta^{13} \mathrm{C}$ values of the $n$-alkanes during heating, at least not in any systematic way that we could identify, 310 given that we did not measure $\delta^{13} \mathrm{C}$ values of other precursor compounds or macromolecules.

312 The results have implications for the interpretations of the $\delta^{13} \mathrm{C}$ values of $n$-alkanes in the sedimentary

313 archive. For example, they suggest that the $\delta^{13}$ Cvalues of $n$-alkanes are unaltered up to hydrous pyrolysis 314 temperatures of 200 to $250{ }^{\circ} \mathrm{C}$ or pre-oil generation window (Peters et al., 2005; Jaeschke et al., 315 2008).Above those temperatures, $\delta^{13} \mathrm{C}$ values of the $n$-alkanes shift. The magnitude and direction of the 316 change is variable among species and chain length, but generally ca. $2 \%$. This is consistent with studies 317 that have examined the effect of maturation on $n$-alkanes within the oil window. For example, $\delta^{13} \mathrm{C}$ values 
of $n$-alkanes are progressively altered with increasing maturity, with the largest changes in the mid to

319 upper oil window (Bjorøy et al., 1992; Clayton and Bjorøy, 1994).

\section{Conclusions}

322 We examined the role that maturation, simulated using hydrous pyrolysis, plays in altering plant

323 biomarkers. With increasing temperature, functionalized di- and triterpenoid yield decreased, with a

324 greater loss of triterpenoids at lower maturation temperature. In contrast, diterpene yield increased up to

325310 to $320^{\circ} \mathrm{C}$. Importantly, triterpenols were preferentially converted to triterpenes over triterpenoic

326 acids. This observation should be examined for other species and terpenoid compounds and

327 functionalities to determine if this is a common pattern. If so, it could help reconcile differences in 328 terpenoid preservation for paleovegetation reconstruction.

330 For the $n$-alkyl lipids, several important generalizations could be made. The $n$-alkanes largely increased in 331 yield up to $320^{\circ} \mathrm{C}$. In contrast, the $n$-alkanols and $n$-alkanoic acids decreased, although not uniformly.

332 The $\delta^{13} \mathrm{C}$ values of the $n$-alkanes were for the most part constant up to $200{ }^{\circ} \mathrm{C}$. Above $200{ }^{\circ} \mathrm{C}$, the total 333 change in $\delta^{13} \mathrm{C}$ varied by chain length, but in general was ca. $2 \%$. This suggests that $n$-alkane $\delta^{13} \mathrm{C}$ values 334 should be unaltered in immature rocks, but could vary in the catagenic stage of maturation (oil window).

\section{Acknowledgements}

We thank N.S. Gupta and A. Riboulleau for helpful comments. We also thank Y.J. Suh and J. Marsh for

339 assistance with sample preparation. D.T.S. completed much of the project as part of his undergraduate

340 senior thesis. We also thank J.M. Moldowan at Biomarker Technologies for helpful comments and, along

341 with D. Zinniker, for technical advice on hydrous pyrolysis. The research was supported by the National

342 Science Foundation (EAR-1229114 to A.F.D.). 
Acknowledgment is made to the Donors of the American Chemical Society Petroleum Research Fund for partial support of the research (PRF \#51787-DNI2 to A.F.D. and \#47367-B2 to D.W.T.).

Associate Editor - P. Schaeffer

\section{Appendix A. Supplementary data}

The supplementary data file includes sample specific information and lipid concentration and yield (Table A.1), the compound-specific carbon isotope data (Table A.2) and information on the unknown compounds observed in the samples (Table A.3).

\section{References}

Bechtel, A., Sachsenhofer, R.F., Kolcon, I., Gratzer, R., Otto, A., Püttmann, W., 2002. Organic geochemistry of the Lower Miocene Oberdorf lignite (Styrian Basin, Austria): its relation to petrography, palynology and the palaeoenvironment. International Journal of Coal Geology 51, $31-57$.

Bechtel, A., Sachsenhofer, R.F., Markic, M., Gratzer, R., Lücke, A., Püttmann, W., 2003. Paleoenvironmental implications from biomarker and stable isotope investigations on the Pliocene Velenje lignite seam (Slovenia). Organic Geochemistry 34, 1277-1298.

Bechtel, A., Gratzer, R., Sachsenhofer, R.F., Gusterhuber, J., Lücke, A., Püttmann, W., 2008. Biomarker and carbon isotope variation in coal and fossil wood of Central Europe through the Cenozoic. Palaeogeography, Palaeoclimatology, Palaeoecology 262, 166-175.

Bjorøy, M., Hall, P.B., Hustad, E., Williams, J.A., 1992. Variation in stable carbon isotope ratios of individual hydrocarbons as a function of artificial maturity. Organic Geochemistry 19, 89-105. 
Bush, R.T., McInerney, F.A., 2013. Leaf wax $n$-alkane distributions in and across modern plants: Implications for paleoecology and chemotaxonomy. Geochimica et Cosmochimica Acta 117, 161-179.

Chaffee, A.L., Johns, R.B., 1983. Polycyclic aromatic hydrocarbons in Australian coals. I. Angularly fused pentacyclic tri- and tetraaromatic components of Victorian brown coal. Geochimica et Cosmochimica Acta 47, 2141-2155.

Clayton, C.J., Bjorøy, M., 1994. Effect of maturity on ${ }^{13} \mathrm{C} /{ }^{12} \mathrm{C}$ ratios of individual compounds in North Sea oils. Organic Geochemistry 21, 737-750.

Diefendorf, A.F., Freeman, K.H., Wing, S.L., Graham, H.V., 2011. Production of $n$-alkyl lipids in living plants and implications for the geologic past. Geochimica et Cosmochimica Acta 75, 7472-7485.

Diefendorf, A.F., Freeman, K.H., Wing, S.L., 2012. Distribution and carbon isotope patterns of diterpenoids and triterpenoids in modern temperate $\mathrm{C}_{3}$ trees and their geochemical significance. Geochimica et Cosmochimica Acta 85, 342-356.

Diefendorf, A.F., Freeman, K.H., Wing, S.L., 2014. A comparison of terpenoid and leaf fossil vegetation proxies in Paleocene and Eocene Bighorn Basin sediments. Organic Geochemistry 71, 30-42.

Egenberg, I.M., Aasen, J.A.B., Holtekjølen, A.K., Lundanes, E., 2002. Characterisation of traditionally kiln produced pine tar by gas chromatography-mass spectrometry. Journal of Analytical and Applied Pyrolysis 62, 143-155.

Eglinton, G., Hamilton, R.J., 1967. Leaf epicuticular waxes. Science 156, 1322-1335.

Eglinton, T.I., 1994. Carbon isotopic evidence for the origin of macromolecular aliphatic structures in kerogen. Organic Geochemistry 21, 721-735.

Farrimond, P., Taylor, A., Telnæs, N., 1998. Biomarker maturity parameters: the role of generation and thermal degradation. Organic Geochemistry 29, 1181-1197.

Finch, P., Freeman, G., 2001. Simulated diagenesis of plant cuticles — implications for organic fossilisation. Journal of Analytical and Applied Pyrolysis 58-59, 229-235. 
Freeman, K.H., Pancost, R.D., 2014. 12.15 - Biomarkers for terrestrial plants and climate. In: Turekian, H.D., Holland, K.K. (Eds.), Treatise on Geochemistry (Second Edition). Elsevier, pp. 395-416.

Frenkel, M., Heller-Kallai, L., 1977. Aromatization of limonene-a geochemical model. Organic Geochemistry 1, 3-5.

Gupta, N.S., Collinson, M.E., Briggs, D.E.G., Evershed, R.P., Pancost, R.D., 2006. Reinvestigation of the occurrence of cutan in plants: implications for the leaf fossil record. Paleobiology 32, 432-449.

Gupta, N.S., Briggs, D.E.G., Collinson, M.E., Evershed, R.P., Michels, R., Jack, K.S., Pancost, R.D., 2007a. Evidence for the in situ polymerisation of labile aliphatic organic compounds during the preservation of fossil leaves: Implications for organic matter preservation. Organic Geochemistry $38,499-522$.

Gupta, N.S., Michels, R., Briggs, D.E.G., Collinson, M.E., Evershed, R.P., Pancost, R.D., $2007 b$. Experimental evidence for the formation of geomacromolecules from plant leaf lipids. Organic Geochemistry 38, 28-36.

Gupta, N.S., 2014. Distribution of cutan in modern leaves. Biopolymers, 38, Topics in Geobiology, Springer Netherlands, pp. 17-41.

Handley, L., Pearson, P.N., McMillan, I.K., Pancost, R.D., 2008. Large terrestrial and marine carbon and hydrogen isotope excursions in a new Paleocene/Eocene boundary section from Tanzania. Earth and Planetary Science Letters 275, 17-25.

Hautevelle, Y., Michels, R., Lannuzel, F., Malartre, F., Trouiller, A., 2006a. Confined pyrolysis of extant land plants: A contribution to palaeochemotaxonomy. Organic Geochemistry 37, 1546-1561.

Hautevelle, Y., Michels, R., Malartre, F., Trouiller, A., 2006b. Vascular plant biomarkers as proxies for palaeoflora and palaeoclimatic changes at the Dogger/Malm transition of the Paris Basin (France). Organic Geochemistry 37, 610-625.

Hayatsu, R., Botto, R.E., Scott, R.G., McBeth, R.L., Winans, R.E., 1987. Thermal catalytic transformation of pentacyclic triterpenoids: Alteration of geochemical fossils during coalification. Organic Geochemistry 11, 245-250. 
Hedges, J.I., Prahl, F.G., 1993. Early diagenesis: consequences for applications of molecular biomarkers. In: Engel, M.H., Macko, S.A. (Eds.), Organic Geochemistry - Principles and Applications. Plenum Press, pp. 237-253.

Jacob, J., Disnar, J.-R., Boussafir, M., Spadano Albuquerque, A.L., Sifeddine, A., Turcq, B., 2007. Contrasted distributions of triterpene derivatives in the sediments of Lake Caçó reflect paleoenvironmental changes during the last 20,000 yrs in NE Brazil. Organic Geochemistry 38, 180-197.

Jaeschke, A., Lewan, M.D., Hopmans, E.C., Schouten, S., Sinninghe Damsté, J.S., 2008. Thermal stability of ladderane lipids as determined by hydrous pyrolysis. Organic Geochemistry 39,1735 1741.

Killops, S.D., Frewin, N.L., 1994. Triterpenoid diagenesis and cuticular preservation. Organic Geochemistry 21, 1193-1209.

Lewan, M., 1993. Laboratory simulation of petroleum formation. In: Engel, M.H., Macko, S.A. (Eds.), Organic Geochemistry. Springer, pp. 419-442.

Lewan, M.D., Winters, J.C., McDonald, J.H., 1979. Generation of oil-like pyrolyzates from organic-rich shales. Science 203, 897-899.

Lu, Y., Hautevelle, Y., Michels, R., 2013. Determination of the molecular signature of fossil conifers by experimental palaeochemotaxonomy - Part 1: The Araucariaceae family. Biogeosciences 10, 1943-1962.

Marzi, R., Torkelson, B.E., Olson, R.K., 1993. A revised carbon preference index. Organic Geochemistry 20, 1303-1306.

Michels, R., Landais, P., 1994. Artificial coalification: Comparison of confined pyrolysis and hydrous pyrolysis. Fuel 73, 1691-1696.

Michels, R., Landais, P., Torkelson, B.E., Philp, R.P., 1995a. Effects of effluents and water pressure on oil generation during confined pyrolysis and high-pressure hydrous pyrolysis. Geochimica et Cosmochimica Acta 59, 1589-1604. 
Michels, R., Landis, P., Philp, R.P., Torkelson, B.E., 1995b. Influence of pressure and the presence of water on the evolution of the residual kerogen during confined, hydrous, and high-pressure hydrous pyrolysis of woodford shale. Energy \& Fuels 9, 204-215.

Moldowan, J.M., Dahl, J., Huizinga, B.J., Fago, F.J., Hickey, L.J., Peakman, T.M., Taylor, D.W., 1994. The molecular fossil record of oleanane and its relation to angiosperms. Science 265, 768-771.

Nakamura, H., Sawada, K., Takahashi, M., 2010. Aliphatic and aromatic terpenoid biomarkers in Cretaceous and Paleogene angiosperm fossils from Japan. Organic Geochemistry 41, 975-980.

Otto, A., Walther, H., Püttmann, W., 1997. Sesqui- and diterpenoid biomarkers preserved in Taxodiumrich Oligocene oxbow lake clays, Weisselster basin, Germany. Organic Geochemistry 26, 105 115.

Otto, A., Simoneit, B.R.T., 2001. Chemosystematics and diagenesis of terpenoids in fossil conifer species and sediment from the Eocene Zeitz formation, Saxony, Germany. Geochimica et Cosmochimica Acta 65, 3505-3527.

Otto, A., Simoneit, B.R.T., Rember, W.C., 2005. Conifer and angiosperm biomarkers in clay sediments and fossil plants from the Miocene Clarkia Formation, Idaho, USA. Organic Geochemistry 36, 907-922.

Pancost, R.D., Boot, C.S., 2004. The palaeoclimatic utility of terrestrial biomarkers in marine sediments. Marine Chemistry 92, 239-261.

Peters, K.E., Moldowan, J.M., Sundararaman, P., 1990. Effects of hydrous pyrolysis on biomarker thermal maturity parameters: Monterey Phosphatic and Siliceous members. Organic Geochemistry 15, 249-265.

Peters, K.E., Walters, C.C., Moldowan, J.M., 2005. The Biomarker Guide. Volume 2: Biomarkers and Isotopes in Petroleum Exploration and Earth History, 2nd ed. Cambridge University Press, Cambridge, UK, $1155 \mathrm{pp}$. 
Rommerskirchen, F., Plader, A., Eglinton, G., Chikaraishi, Y., Rullkötter, J., 2006. Chemotaxonomic significance of distribution and stable carbon isotopic composition of long-chain alkanes and alkan-1-ols in C4 grass waxes. Organic Geochemistry 37, 1303-1332.

Rullkötter, J., Peakman, T.M., ten Haven, H.L., 1994. Early diagenesis of terrigenous triterpenoids and its implications for petroleum geochemistry. Organic Geochemistry 21, 215-233.

Schnell, G., Schaeffer, P., Tardivon, H., Motsch, E., Connan, J., Ertlen, D., Schwartz, D., Schneider, N., Adam, P., 2014. Contrasting diagenetic pathways of higher plant triterpenoids in buried wood as a function of tree species. Organic Geochemistry 66, 107-124.

Sessions, A.L., 2006. Seasonal changes in D/H fractionation accompanying lipid biosynthesis in Spartina alterniflora. Geochimica et Cosmochimica Acta 70, 2153-2162.

Simoneit, B.R.T., 1986. Cyclic terpenoids in the geosphere. In: Johns, R.B. (Ed.), Biological Markers in the Sedimentary Record. Elsevier, pp. 43-99.

Smith, F.A., Wing, S.L., Freeman, K.H., 2007. Magnitude of the carbon isotope excursion at the Paleocene-Eocene thermal maximum: The role of plant community change. Earth and Planetary Science Letters 262, 50-65.

Stankiewicz, B.A., Briggs, D.E.G., Michels, R., Collinson, M.E., Flannery, M.B., Evershed, R.P., 2000. Alternative origin of aliphatic polymer in kerogen. Geology 28, 559-562.

Stout, S.A., 1992. Aliphatic and aromatic triterpenoid hydrocarbons in Tertiary angiospermous lignite. Organic Geochemistry 18, 51-66.

Taylor, D.W., Li, H., Dahl, J., Fago, F.J., Zinniker, D., Moldowan, J.M., 2006. Biogeochemical evidence for the presence of the angiosperm molecular fossil oleanane in Paleozoic and Mesozoic nonangiospermous fossils. Paleobiology 32, 179-190.

ten Haven, H.L., Rullkötter, J., 1988. The diagenetic fate of taraxer-14-ene and oleanene isomers. Geochimica et Cosmochimica Acta 52, 2543-2548. 
ten Haven, H.L., Peakman, T.M., Rullkötter, J., 1992. Early diagenetic transformation of higher-plant triterpenoids in deep-sea sediments from Baffin Bay. Geochimica et Cosmochimica Acta 56, 2001-2024.

Tipple, B.J., Pagani, M., 2013. Environmental control on eastern broadleaf forest species' leaf wax distributions and D/H ratios. Geochimica et Cosmochimica Acta 111, 64-77.

Tissot, B.P., Welte, D.H., 1984. Petroleum Formation and Occurrence, 2nd ed. Springer-Verlag, New York, $699 \mathrm{pp}$.

Vandenbroucke, M., Largeau, C., 2007. Kerogen origin, evolution and structure. Organic Geochemistry $38,719-833$.

Vogts, A., Moossen, H., Rommerskirchen, F., Rullkötter, J., 2009. Distribution patterns and stable carbon isotopic composition of alkanes and alkan-1-ols from plant waxes of African rain forest and savanna $\mathrm{C}_{3}$ species. Organic Geochemistry 40, 1037-1054.

Wakeham, S.G., Schaffner, C., Giger, W., 1980. Polycyclic aromatic hydrocarbons in recent lake sediments--II. Compounds derived from biogenic precursors during early diagenesis. Geochimica et Cosmochimica Acta 44, 415-429.

Whiteside, J.H., Olsen, P.E., Eglinton, T., Brookfield, M.E., Sambrotto, R.N., 2010. Compound-specific carbon isotopes from Earth, largest flood basalt eruptions directly linked to the end-Triassic mass extinction. Proceedings of the National Academy of Sciences of the USA 107, 6721-6725. 


\section{Figure Captions:}

514 Fig. 1. Proportion (\%) of pyrolysate relative to starting weight, as a function of hydrous pyrolysis

515 temperature.

517 Fig. 2. Di- and triterpenoid concentration and yiels( $\mu \mathrm{g} / \mathrm{g}$ dry biomass) as a function of hydrous pyrolysis 518 temperature. For each species, the total functionalized terpenoids, as acids and alcohols, are shown with 519 open circles and the hydrocarbons with filled circles. Unaltered samples are plotted at $25{ }^{\circ} \mathrm{C}$ with standard 520 errors shown.

Fig. 3. $n$-Alkane, $n$-alkanoic acid and $n$-alkanol concentration and yield ( $\mu \mathrm{g} / \mathrm{g}$ of starting material), ACL and CPI vs. hydrous pyrolysis temperature. Unaltered samples are plotted at $25^{\circ} \mathrm{C}$. Error bars are

524 standard errors about the mean for sample replicates.

Fig. 4. Partial GC-FID chromatograms of maltene fraction isolated from the bitumen following hydrous

528 the most abundant chain length labeled; Sq, squalene; Ol, oleanenes; Fr, friedelin; IS, internal standard (1529 1'-binaphthyl).

Fig. 5. Carbon isotopic composition of $n-\mathrm{C}_{27}$ to $n-\mathrm{C}_{33}$ alkanes from hydrous pyrolysis, together with the

$533 n$-alkanoic acids are shown in the shaded areas on the left of each plot. Standard errors are shown for 534 samples with replicate $\delta^{13} \mathrm{C}$ analyses. 


\section{Fig 1}

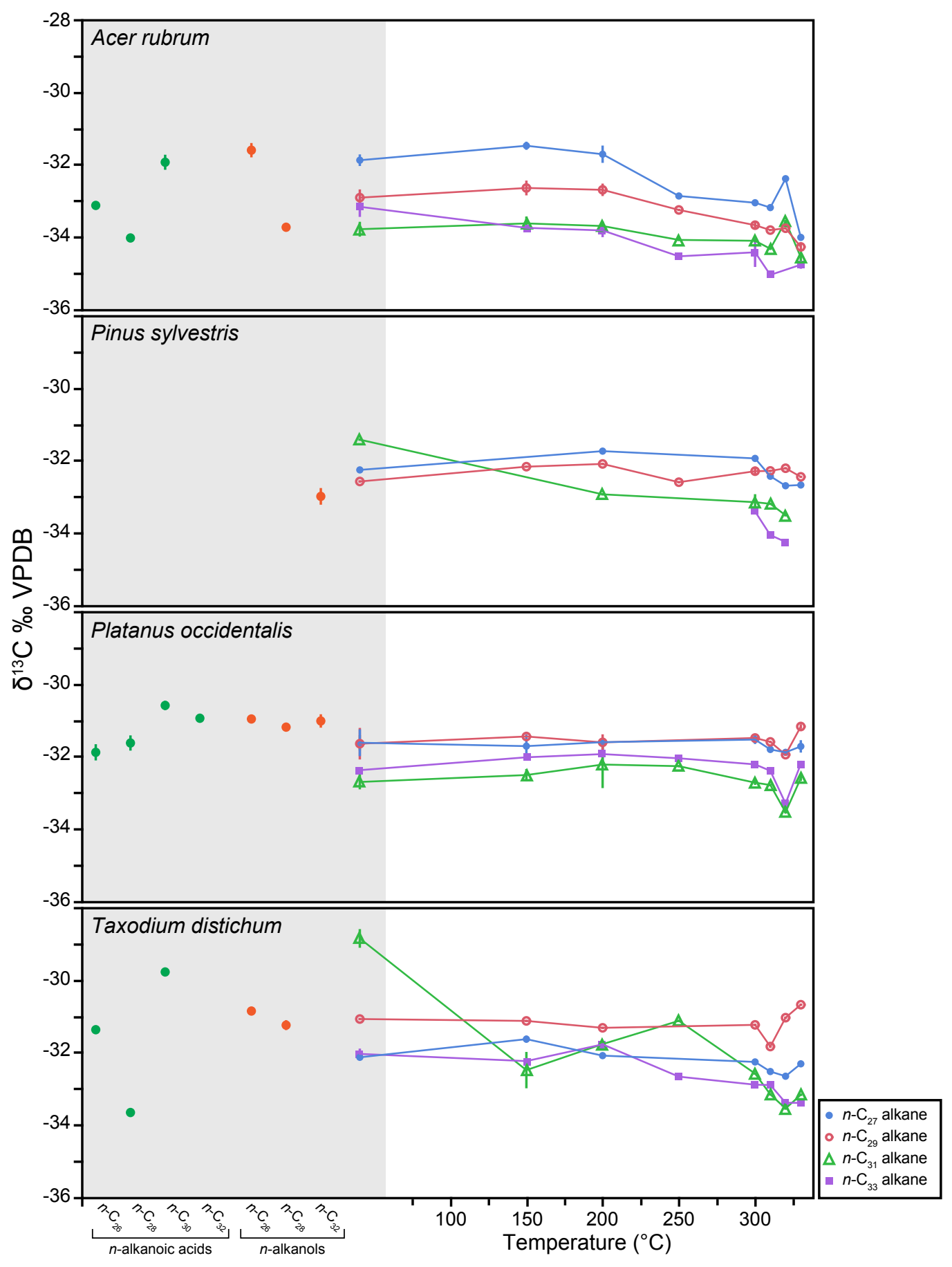


Fig 2

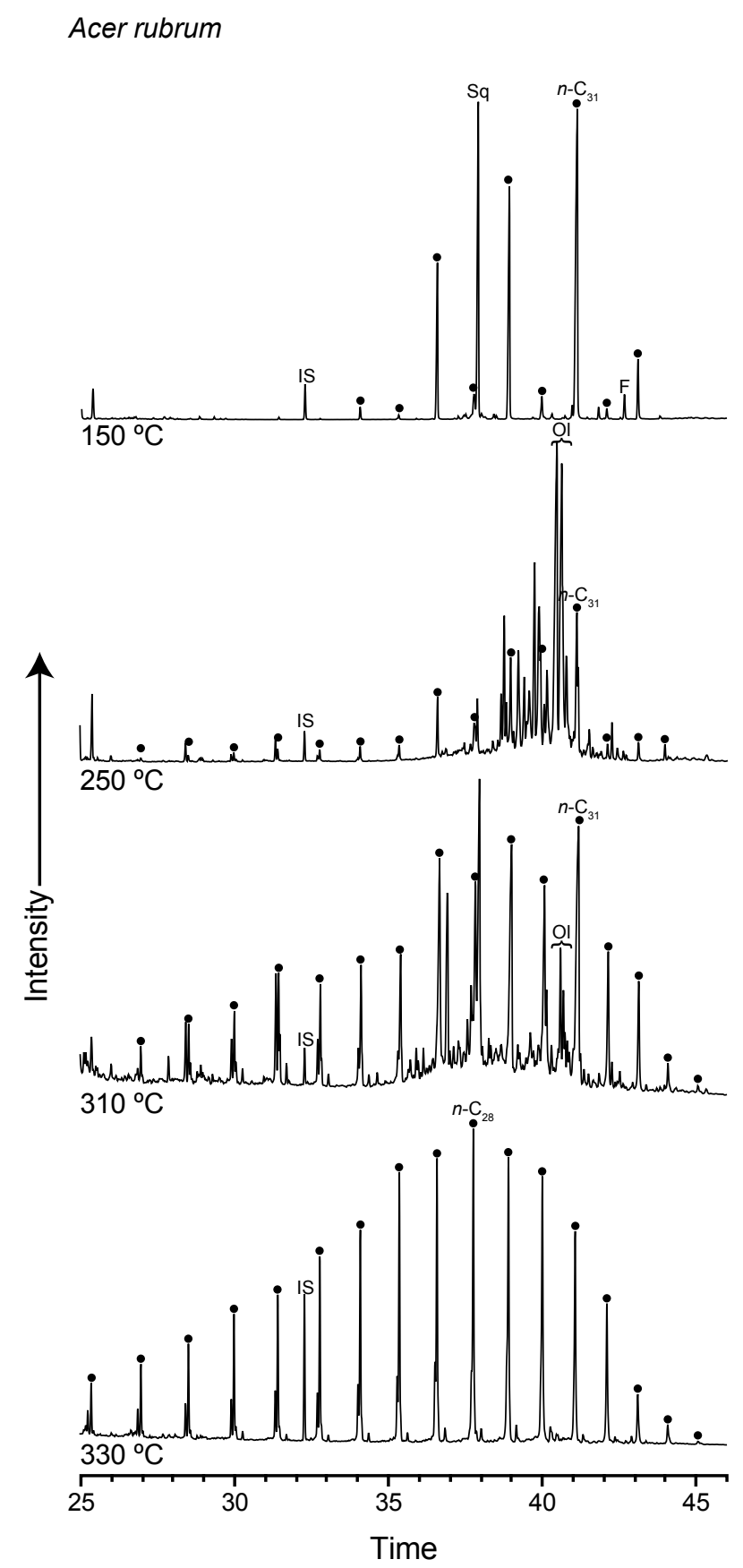


Fig 3

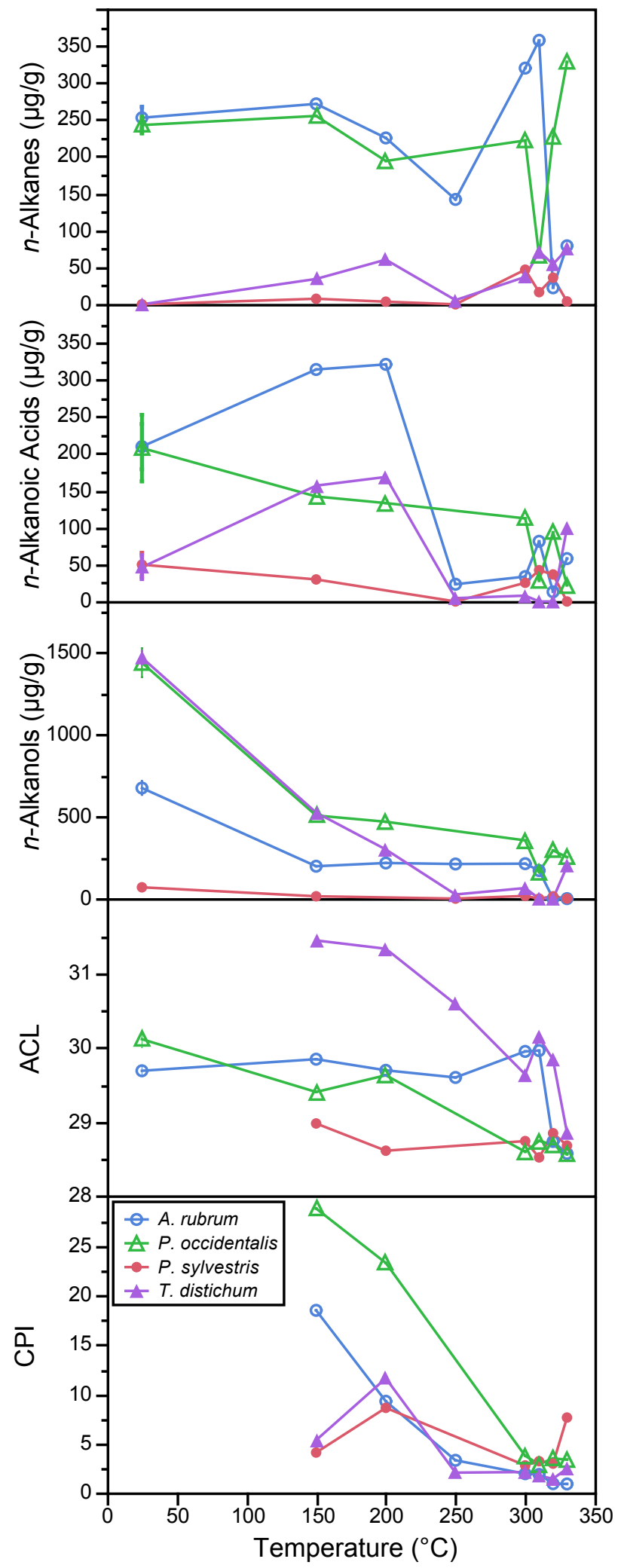


Fig 4
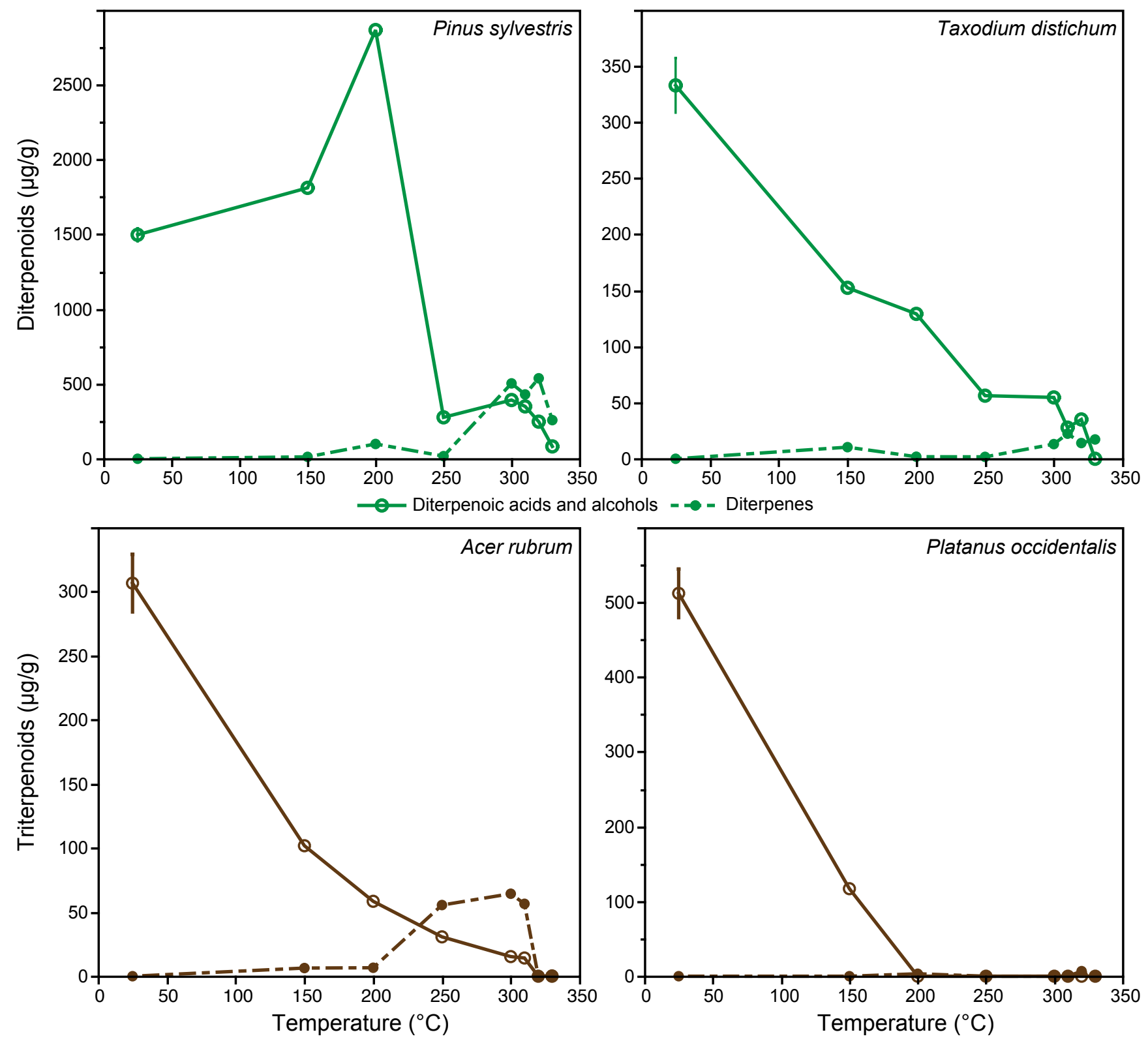

$\multimap$ Triterpenoic acids and alcohols $-\rightarrow-$ Triterpenes 
Fig 5

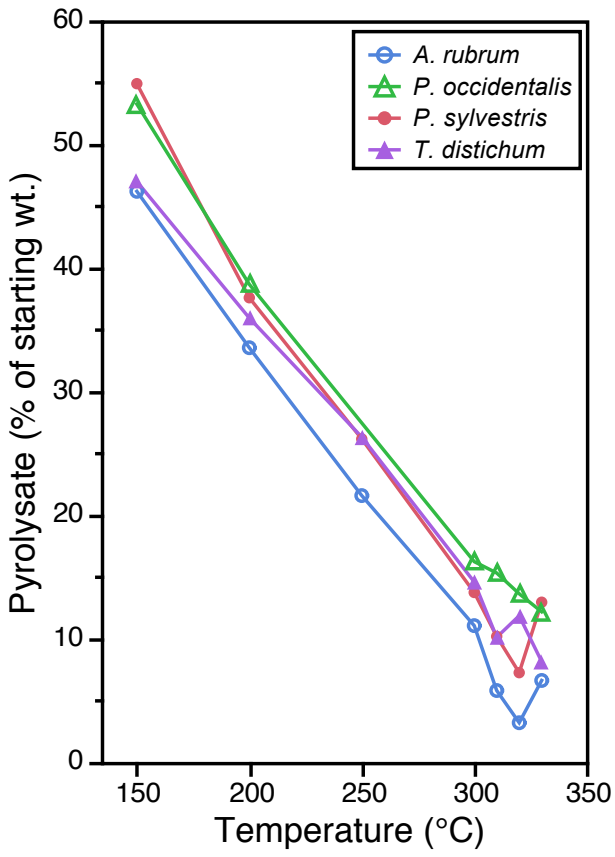

